\title{
The Effect of Service Quality on Patient Loyalty (A Study on Inpatients of Regional Public Hospitals in Jakarta, Indonesia)
}

\author{
Ellynia $^{1}$, Andrianto Widjaja ${ }^{2}$
}

\author{
${ }^{1}$ Husada Hospital School of Health Sciences, Jakarta, Indonesia \\ Email: aay el@yahoo.com \\ ${ }^{2}$ Husada Hospital School of Health Sciences, Jakarta, Indonesia \\ Email: and_widjaja@yahoo.com
}

\begin{abstract}
This study aims at examining whether service quality influences customer loyalty, in this case, hospital's inpatient. Service quality is represented in the form of five independent variables, which are tangibles, reliability, responsiveness, assurance, and empathy. This study is conducted at some regional hospitals in Jakarta, Indonesia, and the respondents are inpatients of the concerned hospitals. The data are analyzed by employing a multiple linear regression method. The research shows that the five independent variables simultaneously, significantly influence patient loyalty. Partially, almost all of the independent variables significantly influence it except the reliability variable.
\end{abstract}

Keywords - Service quality, tangibles, reliability, responsiveness, assurance, empathy, patient loyalty.

\section{INTRODUCTION}

Indonesia's current Health Spending per Capita is still far lower than that of developed countries, even still below that of neighboring Asean countries such as Thailand, Malaysia and, moreover, Singapore. The total percentage of health spending is still about $3.3 \%$ of Indonesia's GDP or one of the lowest in Asean (Health SDG Profile, 2018). One of the reasons is the lack of hospitals, both in quantity and quality. The ratio of Indonesia's hospital bed to patient is currently about 1:900, compared to the average ratio of ASEAN countries of 1:303 (Nurcahyadi, 2016). However, in the last few years, there is a promising growth in the quantity. The data show an average growth of $5.2 \%$ of the number of hospitals in Indonesia since 2012. There are 2820 identified hospitals in April 2018, consisting of 1804 units owned by Private sector and 1016 units owned by the Government (Trisnantoro et al., 2018). The growth also occurs to the number of hospitals in DKI Jakarta province as the state capital, from 159 units in 2014 to 187 units in 2017 (Profil DKI, 2017). It is reasonable that Jakarta's population increases, either its permanent, urban or immigrant population for employment or business. The need for urban health service keeps increasing that people's awareness of the importance of health also improves.

Business competition is currently not only correlated with product's physical form, but also "before and after sales service" (Sivadas et al., 2000). The role of service quality is acknowledged to be a critical determinant for a company's success. Bad service will decrease customer satisfaction level, moreover, current consumers are more aware of rising standards in service which have developed higher expectations. Service quality will cause customer satisfaction, retention, repurchase, customer loyalty, and even market share and profitability (Tjiptono, 2019). This rule is also felt in hospital industry, which is in a more competitive environment. Hospital is an organization which sells health services. Competition in maintaining customers is not only influenced by the availability of physicians and ease of payment, but also by the quality of all services provided to patients. Patient satisfaction is closely related to the quality of services provided by hospital (Kurniawan et al., 2019). Patient satisfaction will then lead to loyalty. On the contrary, dissatisfied patient will move to another hospital which provides better services.

By management, hospital may be classified into: (1) public hospital, managed by the government and nonprofit legal entity, (2) private hospital, managed by legal entity with profit orientation. Various types of existing hospitals attempt to acquire the community's trust by giving quality health services. Such health services include medical service, medical support, medical rehabilitation and treatment service. The services are performed through emergency unit, outpatient unit, and inpatient unit 
(Herlambang, 2016). There are relatively many government-owned hospitals in Jakarta, consisting of 3 central public hospitals (RSUP) and 25 regional public hospitals (RSUD) (http://sirs.yankes.kemkes.go.id/). In the report of survey on the Community Satisfaction Index issued by the Indonesian Ministry of Health 2017, the community is satisfied with services given by RSUP. Moreover, according to the analysis on Consumer Loyalty, more than $80 \%$ users answer that they are likely to reuse the concerned hospitals' services, and above 90\% users answer that they will recommend the hospitals to others. However, the impression of RSUD is different. Regional public hospitals have relatively limited facilities and infrastructure as well as the availability of human resources. However, in comparison with private hospitals at the same level, RSUDs need to improve their service quality.

In this study, the survey is conducted with regional public hospitals in Jakarta managed by local governments, with inpatients treated in some of the hospitals as the research's subjects. For the inpatients, satisfaction level is influenced from registration process, medical action at emergency unit, cleanliness and comfort of treatment room, medical staff and paramedic's attitude and behavior, to the quality of meal given to patient (Setiawan, 2011). In detail, the purpose of this study is to examine and analyze whether Health Service Quality given by regional public hospitals influences Inpatient Loyalty at the concerned hospitals.

\section{LITERATURE REVIEW}

\subsection{Service Quality}

Service quality is deemed as strategic weapon in a service oriented industry, as well as a source of competitive advantage. Parasuraman et al. (1985) define Service Quality as a global assessment or attitude with regard to a service's superiority. He emphasizes that the two main factors to influence service quality are expected service and perceived service. Wyckof (in Lovelock (1988)) describes service quality as the expected level of advantage and control over such advantage in meeting customer's expectation. According to Bitner and Hubbert (1994, in Kondasani et al. (2015)), service quality is the consumer's overall impression of the relative inferiority/ superiority of the organization and its services. In healthcare sector, particularly in hospital industry, service quality is generally viewed as an outcome. Services given by a hospital may be divided into medical and non-medical aspects. The medical aspect includes its supports, consisting of human resources, both in quantity and quality, as well as various instruments for disease diagnosis and treatment purpose. Non-medical aspect consists of information, administration, finance, nutrition, pharmacy, cleanliness and security of hospital environment services (Gonzales in Zulhafiqi (2014)).

The concept of service quality itself has actually developed since 1970. Various opinions arise, such as that of Gronroos (1984), that there are two attributes related to service quality, which are technical and functional aspects. Technical aspect is a process related to the quality of equipment, duty timings, prescription etc., while functional aspect is related to the routine operations, including interaction with customers. A good service quality will certainly raise customer satisfaction, and Kotler et al. (2006) remind that the managements must be concerned about the four service characteristics, including: intangibility, perishability, inseparability, and heterogeneity. Evans and Lindsay (2012, in Afridi et al. (2018)) introduce eight dimensions of service quality, including: time, timeliness, completeness, courtesy, consistency, accessibility, accuracy and responsiveness. Buyukozkan et al. (2011) describe healthcare service quality in six dimensions, including: tangibles, responsiveness, reliability, assurance, empathy and professionalism. Many researches on health industry prove that Service Quality significantly influences patient satisfaction and loyalty. The research conducted by Shabbir et al. (2016) on hospital industry in Pakistan proves that perceived service quality has a significant positive effect on patients' loyalty. Their research is conducted on inpatients of both public and private hospitals. Meanwhile, the research conducted by Kaffashi et al. (2014) on outpatients finds relationship between outpatient service quality and patients' loyalty in selected public hospital in Iran. A similar result is also reported by the research conducted by Fatima et al. (2018), proving that healthcare service quality aspects (physical environment, customer-friendly environment, responsiveness, communication, privacy and safety) are positively related with patient loyalty which is mediated through patient satisfaction. With regard to the influence of an increase of service quality on satisfaction and loyalty, the research conducted by Ping Lei et al. (2012) on Chinese healthcare system shows that the most appropriate model to describe this situation is that service quality will influence loyalty mediated by satisfaction variable.

The popular service quality model often referred to in marketing researches is the SERVQUAL model (abbreviation of service quality), developed by Parasuraman et al. (1985). The model includes analysis on 5 gaps which will determine how good a company's 
service quality is. The five gaps may be broken down as follows (Tjiptono, 2019): (1) gap between consumer's expectation and management's perception of customer's expectation (knowledge gap), (2) difference between management's perception of consumer's expectation and service quality specification (standards gap), (3) difference between service quality specification and service delivery (delivery gap), (4) difference between service delivery and external communication (communications gap), and (5) gap between perceived service and expected service (service gap). The fifth gap is represented through customer's perspective on the five dimensions of service quality. Parasuraman et al. (1988, in Tjiptono (2019) propose the servqual model to assess service quality, in which the model contains five main dimensions, namely:

1. Reliability; is the ability to provide promised service immediately, accurately and satisfactorily.

2. Responsiveness; is staffs' desire to help customers and provide services responsively.

3. Assurance; covers staffs' knowledge, competence, politeness and trusted characteristics, and free from risk and doubt.

4. Empathy; is the ability to have a good relationship and communication, personal attention and understanding of customers' needs.

5. Tangibles; includes physical facilities, equipment, employees and means of communication.

Initially, using Factor analysis, Parasuraman et al. successfully identify 10 dimensions out of the 22 questions asked in evaluating service quality. After passing empirical test, the servqual model is modified to 5 dimensions only. In this study, the author employs the servqual model with five dimensions above, with research instrument modified by James Carman to be specifically applied to hospital industry (Zaim et al., 2010).

\subsection{Customer Loyalty}

Many companies start to be aware that customer satisfaction is not their final objective, moreover, many competitors provide customers with many alternative suppliers. Satisfaction is an individual's attitude, while loyalty is buying behavior. A loyal customer is an individual that makes regular repurchase, invulnerable to any of competitor's persuasion, and even willing to recommend the concerned product to others. Therefore, customer satisfaction will be meaningful when it leads to Customer Loyalty. According to Schnaars (1998), there are four possibilities of relationship between customer satisfaction and loyalty, namely: (a) failures, in which customer is dissatisfied and disloyal; (b) forced loyalty, dissatisfied but bound to promotional program, as if it is loyal; (c) defectors, customer is satisfied but disloyal; (d) successes, customer is satisfied, loyal and may serve as a word-of-mouth advertiser. Fornell (1992, in Ahmed et al. (2017)) states that loyal customers are not necessarily satisfied, but satisfied customers must be loyal customers. Yarmen et al. (2016) in their research define loyalty as customer commitment on still using a certain service provider even though he/she has opportunity and resources to switch to other providers. Griffin (2005) represents customer loyalty as a more reliable measure than customer satisfaction factors to predict company's sales growth. Gelis et al. (2017) describe loyal customer as a person who regularly uses a service provider or vendor, repeats to purchase of service or product from the same corporate and does not consider other service providers or vendors. Bowen and Shoemaker (2003) state that loyalty is the attitude of a customer towards a specific company who purchases again and again from the same company, and talks good about the company and provide referrals.

With regard to the health and hospital industry, Engiz (2007, in Asnawi (2019)) describes patient loyalty as the situation that the patient continues the relation with the hospital and recommends the services of the hospital to the potential patients. Anbori et al. (2010, in Ahmed et al. (2017)) represent patient loyalty as a strategic service plan to retain customers in the long term by providing better service quality. When a service provider understands the most important aspects of service quality needed by patients, then this will lead to patient satisfaction and willingness to reuse medical services. Many researches correlate service quality with patient loyalty. The study conducted by Gunawan et al. (2011) with private hospitals in Bali, Indonesia confirms significant influence, both simultaneously and partially, of service quality on patient loyalty. In the study, Parasuraman et al.'s concept (1985) is used for the indicators of service quality variable, while the concept in Baloglu's study (2002) is used for the indicators of loyalty variable, namely: trust, psychological commitment, switching cost, word of mouth, and cooperation. Similar result is also obtained in the study conducted by Asnawi et al. (2019), that a public hospital's service quality will directly influence patient's satisfaction and loyalty. The research conducted by Putu et al. (2018) at a hospital confirms positive and significant influence of service quality on patient loyalty. Putu et al. even find indirect influence between the two variables above mediated by patient satisfaction. This is slightly different from the result of research conducted by As'ad and Noermijati (2011) on a hospital with inpatients as the sample. Service quality variable here does not directly influence patient loyalty, but through customer satisfaction 
variable instead. The study conducted by Afridi et al. (2018) in Peshawar finds significant influence of healthcare quality on patient loyalty. The study also reveals that customer's commitment presents a mediating effect on the correlation of the two variables above. Arab et al. (2012) conduct a study to determine the hospital service quality from the patients' viewpoints and the relative importance of quality dimensions in predicting the patient's loyalty. It turns out that $29 \%$ loyalty variance is explained by service quality dimensions.

Setiawan (2011) presents some factors which may form customer loyalty in hospital industry, namely: (a) customer's sense of belonging through product preferential and differential level; (b) develop switching barrier, through switching cost aspect and social and psychological aspects; (c) generate service quality which may satisfy customer. Meanwhile, Kumar and Shah (2006) divide loyalty into behavioral and attitudinal aspects. Behavioral loyalty refers to the buying characteristics of a buyer, while attitudinal loyalty, on the other hand, is considered to be the pure form of loyalty. Baloglu (2002) introduces five indicators of loyalty, namely: (1) trust, (2) psychological/ emotional commitment, (3) switching cost, (4) word of mouth, and (5) cooperation. The five indicators are actually the detail of behavioral and attitudinal dimensions. Behavioral dimension is sometimes called voluntary partnership, measured through cooperation and word-of-mouth indicators. Cooperation is defined as working together to achieve mutual goals, and it is usually customer's desire to help the concerned company or product. Meanwhile, word-of-mouth involves promoting the company by making positive statements, recommendations, and referrals. Attitudinal dimension measures loyalty through the following indicators: trust, emotional attachment or commitment, and switching cost. Trust may be defined as one's confidence in an exchange partner's reliability and integrity. Emotional attachment or commitment has been defined as liking the partner, enjoying the partnership, and having a sense of belonging to the company. Switching has been defined as the time, effort, and expense associated with switching from one company to another.

\subsection{Conceptual Framework and Hypothesis}

In answering the research's objective, a research model which involves Service Quality variable as the independent variable and Customer Loyalty variable is developed, which in this case is Patient Loyalty, as the dependent variable. Parasuraman et al.'s servqual model with 5 dimensions (1988) is employed to represent Service Quality variable. The five dimensions are taken as the five independent variables, which may operationally defined as follows: (1) Reliability, is the ability to provide promised service accurately and satisfactorily; (2) Responsiveness, is staffs' desire to help customers and provide services responsively; (3) Assurance, covers staffs' knowledge, competence, politeness and trusted characteristics, and free from risk and doubt; (4) Empathy, is the ability to have a good relationship and communication, personal attention and understanding of customers' needs; (5) Tangibles; includes physical facilities, equipment, employees and means of communication. Meanwhile, the Customer Loyalty variable may be defined as a multi-element concept involving both behavioral elements (repeat purchases) and attitudinal elements (commitments). This study employs Baloglu's approach (2002) which introduces five indicators of loyalty, namely: (1) trust, (2) psychological/ emotional commitment, (3) switching cost, (4) word of mouth, and (5) cooperation.

Based on the literature review and research model above, five hypotheses $\mathrm{H} 1$ to $\mathrm{H} 5$ are developed, showing partially significant influence of respectively independent variables (Tangible, Reliability, Responsiveness, Assurance, Empathy) on dependent variable (Customer Loyalty). And, the sixth hypothesis (H6) shows simultaneously significant influence of independent variables on Customer Loyalty variable.

\section{RESEARCH METHOD}

This research is conducted at government-owned hospitals called RSUDs in DKI Jakarta province. According to the record, there are currently 25 RSUDs in Jakarta, 6 units in Central Jakarta, 4 units in West Jakarta, 6 units in South Jakarta, 5 units in East Jakarta and 4 units in North Jakarta. A quantitative method and explanative approach are employed for the analysis, aiming at explaining whether or not some independent variables influence the dependent variable. The samples are taken from the inpatients of three Class A and B regional public hospitals representing Central Jakarta, East Jakarta, and North Jakarta, while 100 respondents are taken out of the inpatients with a convenience sampling method.

Questionnaire is employed as the research instrument to represent the Service Quality variable using the instrument developed by James Carman (Zaim et al., 2010), which is specifically applied to hospital industry. The instrument actually involves six dimensions of service quality, including the 'courtesy' dimension, containing 34 questions. However, this study only utilizes five dimensions of servqual, which are the independent variables (tangible, reliability, responsiveness, assurance, and empathy) containing 29 questions. Meanwhile, the 
customer loyalty variable uses Baloglu's version of indicators (2002) containing 19 questions. A complete test of the research's instrument consisting of validity and reliability test is conducted before data collecting. A multiple linear regression analysis is conducted on the data after meeting the data quality requirement to examine whether or not independent variables influence the dependent variable. $\mathrm{F}$ test and $\mathrm{t}$ test are employed for hypothesis test.

\section{RESEARCH FINDINGS AND DISCUSSION}

The respondents' profiles may be classified by gender, age, education, employment, and duration of hospitalization. According to the collected data, 69 percent of the respondents are women and only 31 percent are men. By age, most of the respondents, 58 percent, are under 25 years old, 17 percent are above 51 years, and the remaining are 26-51 years old. In this research, most of the respondents, 69 percent, coincidentally have High School/Vocational High School education. The other interesting factor is that most of the respondents, 59 percent, are coincidentally unemployed or not yet employed, while the remaining are private employees, entrepreneurs, and housewives. The respondents are deemed relevant to assess the service quality factor, since most of them, 61 percent, has been hospitalized for 4-6 days, 8 percent for 7-15 days, 5 percent more than 15 days, and 26 percent for less than 3 days.

Meanwhile, the data processing using the multiple regression technique results in the outcome as presented in the table below.

Table 1. Result of Multiple Regression Analysis

\begin{tabular}{|l|c|r|r|r|}
\hline Model & $\mathrm{R}$ & R Square & $\begin{array}{c}\text { Adjusted R } \\
\text { Square }\end{array}$ & $\begin{array}{c}\text { Std. Error of } \\
\text { the Estimate }\end{array}$ \\
\hline 1 & $.892^{\mathrm{a}}$ & .796 & .785 & 3.768 \\
\hline
\end{tabular}

\begin{tabular}{|c|c|c|c|c|c|c|}
\hline \multicolumn{7}{|c|}{ ANOVA $^{a}$} \\
\hline Model & & $\begin{array}{c}\text { Sum of } \\
\text { Squares }\end{array}$ & $\mathrm{df}$ & $\begin{array}{l}\text { Mean } \\
\text { Square }\end{array}$ & $\mathrm{F}$ & Sig. \\
\hline \multirow{3}{*}{1} & Regression & 5214.271 & 5 & 1042.854 & 73.458 & $.000^{\circ}$ \\
\hline & Residual & 1334.479 & 94 & 14.197 & & \\
\hline & Total & 6548.750 & 99 & & & \\
\hline
\end{tabular}

\begin{tabular}{|c|c|c|c|c|c|c|}
\hline \multicolumn{7}{|c|}{ Coefficients $^{a}$} \\
\hline \multirow{2}{*}{\multicolumn{2}{|c|}{ Model }} & \multicolumn{2}{|c|}{$\begin{array}{c}\text { Unstandardized } \\
\text { Coefficients }\end{array}$} & $\begin{array}{c}\text { Standardized } \\
\text { Coefficients }\end{array}$ & \multirow[t]{2}{*}{$\mathrm{t}$} & \multirow[t]{2}{*}{ Sig. } \\
\hline & & $B$ & Std. Error & Beta & & \\
\hline \multirow{6}{*}{1} & (Constant) & 6.686 & 3.285 & & 2.036 & .045 \\
\hline & Var_X1 & .611 & .133 & .330 & 4.599 & .000 \\
\hline & Var_X2 & .319 & .210 & .111 & 1.519 & .132 \\
\hline & Var_X3 & .332 & 157 & .172 & 2.111 & .037 \\
\hline & Var_X4 & .933 & .250 & .281 & 3.736 & .000 \\
\hline & Var_X5 & .908 & .390 & .148 & 2.329 & .022 \\
\hline
\end{tabular}

The data processing result shows that $\mathrm{R}$ square value is 0.892 , which means that the percentage of contribution of Tangible (X1), Reliability (X2), Responsiveness (X3), Assurance (X4), and Empathy (X5) variables' influence on Customer loyalty is $89.2 \%$, while the remaining $10.8 \%$ is contributed by other variable not included in this research. This result may be interpreted that hospital's service quality factor (in the form of five dimensions of servqual) plays an important role in determining patient loyalty, particularly for inpatients.

The $F$ count value is 73.458 with significance value of $0.000<0.05$, thus we may conclude that Tangible, Reliability, Responsiveness, Assurance, and Empathy variables simultaneously, significantly influence In-Patient Loyalty. This means that the sixth hypothesis is acceptable. This finding is similar to that of previous researches considerably conducted particularly with regard to hospital industry (Shabbir et al. (2016), Jamaluddin et al. (2017), Fatima et al. (2018), Arab et al. (2012), Putu et al. (2018)). Indeed, not all of the researches represent service quality variable through the servqual's 5 dimensions: Tangible, Reliability, Responsiveness, Assurance, and Empathy. In the research conducted by Shabbir et al. (2016), Healthcare Service Quality variable is represented through physicians care, nurses' care, supportive staff, operational activities, and physical maintenance dimensions. The research conducted by Fatima et al. (2018) employs physical environment, customer-friendly environment, communication, privacy and safety, and responsiveness to represent healthcare service quality. On the other hand, the research conducted by Arab et al. (2012) represents hospital service quality through process quality, interaction quality, environment quality, and costing variables. Meanwhile, the research conducted by As'ad et al. (2011) entitled the influence of service quality and price on customer satisfaction and loyalty, with inpatients as the respondents finds no indirectly significant influence of service quality on patient loyalty.

This study partially finds that four out of the five independent variables, namely Tangibles (X1), Responsiveness (X3), Assurance (X4), and Empathy (X5) variables evidently significantly influence Customer Loyalty variable, as shown with their significance values which are below $5 \%$ of 0.000 for X1, 0.037 for X3, 0.000 for X4, and 0.022 for X5. This means that the first, third, fourth and fifth hypotheses are acceptable. Meanwhile, Reliability variable (X2) does not partially, significantly influence Customer Loyalty, as shown with the significance value of $0.132>0.05$. We may state that the second hypothesis is rejected. This finding is in line with 
the result of research conducted by Kondasani et al. (2015) that one of the dimensions of perceived service quality studied, which is Reliability, evidently does not significantly influence customer loyalty. The study conducted by Kaffashi et al. (2014) on outpatient respondents shows the highest gap between perception and expectation with the Reliability dimension representing health service quality. In addition, the result of data analysis shows that Tangibles variable has the most dominant influence among the service quality's variables. This finding is possibly related to respondents' profiles, that they pay attention more to tangibles factor. Most of the respondents are young, under 25 years old, have High School or Vocational High School education, and are coincidentally mostly unemployed yet.

\section{CONCLUSION}

The result of data analysis shows that all of the hypotheses are acceptable, except the second hypothesis, showing that Reliability variable does not significantly influence Customer Loyalty. Meanwhile, the other variables of Service Quality such as Tangible, Responsiveness, Assurance, and Empathy partially, significantly influence Customer or Patient Loyalty. The five variables of Service Quality simultaneously, significantly influence Patient Loyalty.

The research result cannot be separated from the samples taken, in which the samples are inpatients of some class A and B regional public hospitals, which are hospitals which are relatively able to provide better services. The respondents' profiles also contributively influence the research result. For a result which may represent the actual condition better, it needs to increase the size of samples and involve more regional public hospitals in Jakarta.

\section{REFERENCES}

[1] Afridi, Sajjad Ahmad., and Maqsood Haider. (2018). Impact of healthcare quality on customers' loyalty; mediating effect of customers' commitment: a comparative study of public and private hospitals of Peshawar. The Business and Management Review, 9(4) Juli, p: 529-542.

[2] Ahmed, Selim., Kazi Md. Tarique and Ishtiaque Arif. (2017). Service quality, patient satisfaction and loyalty in the Bangladesh healthcare sector. International Journal of Health Care Quality Assurance, 30(5). p. 477-488.

[3] Anbori, A., Ghani, S.N., Yadav, H., Daher, A.M. and Su, T.T. (2010). Patient satisfaction and loyalty to the private hospitals in Sana'a, Yemen. International Journal for Quality in Health Care, 22(4). p. 310-315.

[4] Arab, M., SM Ghazi Tabatabaei, A Rashidian, A Rahimi Forushani, and E Zarei. (2012) The Effect of Service
Quality on Patient loyalty: a Study of Private Hospitals in Tehran, Iran. Iranian J Publ Health, 41(9), Sep. p.71-77.

[5] As'ad, Achmad Shofiyyuddin., dan Noermijati. (2013). Pengaruh Kualitas Pelayanan dan Harga Terhadap Kepuasan dan Loyalitas Pelanggan (Studi Pada Pasien Rawat Inap di Rumah Sakit NU Tuban). Jurnal Aplikasi Manajemen, 11(3) September. p:399-406.

[6] Asnawi, Assila Anis., Zainudin Awang, Asyraf Afthanorhan, Mahadzirah Mohamad and Fazida Karim. (2019). The influence of hospital image and service quality on patients' satisfaction and loyalty. Management Science Letters 9. p:911-920.

[7] Asnawi, Assila Anis., Zainudin Awang, Asyraf Afthanorhan, Mahadzirah Mohamad and Fazida Karim. (2019). The influence of hospital image and service quality on patients' satisfaction and loyalty. Management Science Letters, 9. p:911-920.

[8] Baloglu, Seyhmus. (2002). Dimensions of Customer Loyalty. European Journal of Marketing. p:1372-1388.

[9] Bitner, M.J. and Hubbert, A.R. (1994). Encounter satisfaction versus overall satisfaction versus quality: the customer's voice. in Rust, R.T. and Oliver, R.L. (Eds) Service Quality: New Directions in Theory and Practice. Sage. Thousand Oaks. CA. p. 72-94.

[10] Bowen, J. T., \& Shoemaker, S. (2003). Loyalty: A strategic commitment. Cornell Hotel and Restaurant Administration Quarterly, 44(5-6). p:31-46.

[11] Buyukozkan, G., Cifci, G. and Guleryuz, S. (2011). Strategic analysis of healthcare service quality using fuzzy AHP methodology", Expert Systems with Applications, 38(8). p: 9407-9424.

[12] Engiz, O. (2007). Sağlık hizmetlerinde hasta tatmini. nternet Adresi. Erişim Tarihi, 10.

[13] Evans, J., \& Lindsay, W. (2012). Managing for quality and performance excellence. Cengage Learning.

[14] Fatima, Taqdees., Shahab Alam Malik, \& Asma ShabbirHospital. (2018). Healthcare Service Quality, Patient Satisfaction, and Loyalty An Investigation in Context of Private Healthcare Yystems. International Journal of Quality \& Reliability Management, 35(6). p. 1195-1214.

[15] Fornell, C. (1992). A national satisfaction barometer: the Swedish experience. Journal of Marketing, 56(1). p. 6-21.

[16] Griffin, Jill. (2005). Customer Loyality Menumbuhkan dan Mempertahankan Kesetiaan Pelanggan. Jakarta: Erlangga.

[17] Grönroos, C. (1984). A service quality model and its marketing implications. European Journal of Marketing, 18(4), p:36-44.

[18] Gunawan, Ketut., \& Sundring Pantja Djati. (2011). Kualitas Layanan dan Loyalitas Pasien (Studi pada Rumah Sakit Umum Swasta di Kota Singaraja-Bali). Jurnal Manajemen dan Kewirausahaan, 13(1) Maret, p:32-39.

[19] Health SDG Profile: Indonesia. (2018). World Health Organization South-East Asia.

[20] Herlambang, Susatyo. (2016). Manajemen Pelayanan Kesehatan Rumah Sakit, Cara Mudah Memahami Manajemen Pelayanan di Rumah Sakit dan Organisasi 
Pelayanan Kesehatan Lainnya. Yogyakarta: Gosyen Publishing.

[21] http://sirs.yankes.kemkes.go.id.

[22] Irnandha, Aris., \& Agung Utama. (2016). The Effect of Service Quality Toward Customer Loyalty Through Customer Satisfaction of Land Line Shipping Services (A Case Study of Satisfaction of JNE Hijrah Sagan Yogyakarta Area). Jurnal Manajemen Bisnis Indonesia, 5(6), p:660-669.

[23] Jamaluddin, and Endang Ruswanti. (2017). Impact of Service Quality and Customer Satisfaction on Customer Loyalty: A Case Study in a Private Hospital in Indonesia. IOSR Journal of Business and Management (IOSR-JBM), 19(5). Ver. I (May). p.23-33.

[24] Kaffashi, Shahnaz., Ali Keshtkaran, Arefeh Pourtaleb, Zohre Nejatzadegan, and Mehdi Raadabadi. (2014). Health Service Quality: Comment on "How Outpatient Service Quality in Hospitals Affects Patients' Loyalty?". Jundishapur Journal of Health Sciences, 6(2), Spring. p: 335-342.

[25] Kementerian Kesehatan Republik Indonesia. (2017). Indeks Kepuasan Masyarakat. Laporan Survey. Kemenkes. Indonesia.

[26] Kondasani, R.K.R. and Panda, R.K. (2015). Customer perceived service quality, satisfaction and loyalty in Indian private healthcare. International Journal of Health Care Quality Assurance, 28(5). p. 452-467.

[27] Kotler, P., Bowen, J. and Makens, J.C. (2006). Marketing for Hospitality and Tourism. Pearson NJ: Prentice Hall.

[28] Kumar, V., Shah, D., \& Venkatesan, R. (2006). Managing retailer profitability - one customer at a time!. Journal of Retailing, 82 (4). p:277-294.

[29] Kurniawan, Aris., Oki Rosanto, \& Marlina Rahmi Shinta. 2019. Pengaruh Kualitas Pelayanan Terhadap Kepuasan Pasien Pada RSUD Budhi Asih Jakarta Timur. Aktiva Jurnal Penelitian Ekonomi dan Bisnis, 3(1) Juli. p:1-10.

[30] Lei, P. and Jolibert, A. (2012). A three-model comparison of the relationship between quality, satisfaction and loyalty: an empirical study of the Chinese healthcare system. BMC Health Services Research, 12(1). p. 436-446.

[31] Lovelock. (1988). Managing Service: Marketing, Operation, and Human Resources. London: Prentice-Hall International, Inc.

[32] Nurcahyadi, Akhmad. (2016). Brighter Year Ahead. Healthcare Sector. Samuel Sekuritas Indonesia.

[33] Parasuraman, A., Zeithaml, V. A., \& Berry, L. L. (1985). A conceptual model of service quality and its implications for future research. The Journal of Marketing. p:41-50.

[34] Parasuraman, A., Zeithaml, V. A., \& Berry, L. L. (1994). Reassessment of expectations as a comparison standard in measuring service quality: implications for further research. The Journal of Marketing. p:111-124.

[35] Parasuraman, A., Zeithaml, V.A., \& Berry, L. (1988). SERQUAL: Multiple-item scale for Measuring consumer Perceptions of Service Quality, Journal ofRetailing, 64(1). P: $12-40$.

[36] Profil Kesehatan DKI. (2017). Provinsi DKI Jakarta.
[37] Putu, Made Adhi Mahendrayana., Ngurah Suyatna, \& Yasa Luh Putu Indiani. (2018). The Effect of Service Quality on Patient Loyalty Mediated by Patient Satisfaction in Bali Siloam Hospital. JAGADHITA:Jurnal Ekonomi \& Bisnis, 5(1) Maret. p: 1-7

[38] Schnaars, S.P. (1998). Marketing Strategy: A Customer Driven Approach. New York: The Free Press.

[39] Setiawan, Supriadi. (2011). Loyalitas Pelanggan Jasa. Bogor: IPB Press.

[40] Shabbir, Asma., Shahab Alam Malik, \& Shujah Alam Malik. 2016. Measuring patients' healthcare service quality perceptions, satisfaction, and loyalty in public and private sector hospitals in Pakistan. International Journal of Quality \& Reliability Management, 33(5). p:538-557.

[41] Sivadas, Eugene., and., Jamie L. Baker-Prewitt. (2000). An Examination of the Relationship Between Service Quality, Customer Satisfaction, and Store Loyality. International Journal of Retail \& Distribution Management, Vol.28. p:73-82.

[42] Tjiptono, Fandy. (2019). Pemasaran Jasa: Prinsip, Penerapan, Penelitiaan. Yogyakarta: Andi.

[43] Trisnantoro, Laksono., \& Elisabeth Listyani. (2018). Jumlah RS di Indonesia Pertumbuhan RS Publik. http://sirs.yankes.kemkes.go.id/rsonline/report/.

[44] Yarmen, Medi., Sik Sumaedi, I Gede Mahatma Yuda Bakti, Tri Rakhmawati, Nidya Judhi Astrini and Tri Widianti. (2016). Investigating patient loyalty An integrated framework for trust, subjective norm, image, and perceived risk (a case study in Depok, Indonesia). International Journal of Quality and Service Sciences, 8(2). p. 179-196.

[45] Zaim, H., Bayyurt, N. and Zaim, S. (2010). Service quality and determinants of customer satisfaction in hospitals: Turkish experience. The International Business and Economics Research Journal, 9(5). p. 51-58.

[46] Zulhafiqi. (2014). Pengaruh Kualitas Pelayanan Kesehatan Terhadap Loyalitas Pasien Pada Badan Layanan Umum Daerah Rumah Sakit Ibu dan Anak Banda Aceh. Tugas Akhir Program Magister. Universitas Terbuka 